Роман Дзюбчук, кандидат технічних наук, старший науковий співробітник Житомирський військовий інститут імені С. П. Корольова

ORCID ID 0000-0001-6224-456X

Григорій Капосльоз, кандидат психологічних наук, старший науковий співробітник, ORCID ID 0000-0001-7369-3977

Олег Розумний Національний університет оборони України імені Івана Черняховського ORCID ID 0000-0003-3225-8375

\title{
МІСЦЕ ТА РОЛЬ НАУКОВИХ ДОСЛІДЖЕНЬ У ЗАБЕЗПЕЧЕННІ ОСВІТНЬОЇ ДІЯЛЬНОСТІ ВИЩОГО ВІЙСЬКОВОГО НАВЧАЛЬНОГО ЗАКЛАДУ ТЕХНІЧНОГО ПРОФІЛЮ ПІДГОТОВКИ
}

У статті визначено місие та роль наукових досліджень у забезпеченні освітньої діяльності вищих військових навчальних закладів (управлінні освітньою діяльністю та розвитком навчального закладу, організачії освітнього процесу на кафедрі), окреслено проблемні питання організації наукових досліджень для забезпечення освітньої діяльності вищого військового навчального закладу та можливі шляхи їх вирішення.

Ключові слова: наукове забезпечення; вищий військовий навчальний заклад; наукове дослідження; модель організації.

Постановка проблеми в загальному вигляді. В умовах ведення Російською Федерацією гібридної війни проти України освітня діяльність вищих військових навчальних закладів (ВВН3) Збройних Сил (ЗС) України спрямовується на формування в курсантів і слухачів уміння виконувати поставлені бойові завдання під час проведення антитерористичної операції в окремих районах Донецької та Луганської областей України (АТO). Уже здійснено перерозподіл навчального навантаження, згідно з яким теоретичні заняття складають 30-40 \% бюджету навчального часу, практичні - 60-70 \%.

Водночас досвід ведення бойових дій провідними (у воєнному відношенні) країнами світу свідчить, що однакових сценаріїв дій не існує, кожна проведена кампанія має «своє обличчя» й відрізняється від попередніх засобами, що залучаються, формами та способами застосування військ. А тому, підготовка має здійснюватися до війн майбутнього із врахуванням перспектив розвитку техніки й озброєння. Окрім того, для ВВНЗ технічного профілю важливою задачею залишається забезпечення високого рівня загально-інженерної підготовки військових фахівців.

У зв'язку з вищевикладеним, у ВВНЗ технічного профілю виникає необхідність проведення наукових досліджень для задоволення низки взаємопов'язаних потреб військової освіти, а саме: 
- поєднати високу практичну підготовленість випускника до експлуатації та застосування за призначенням озброєння і військової техніки (OBT), якими оснащені Збройні Сили України, та його готовність до освоєння, модернізації, розроблення перспективних зразків ОВТ;

- здійснити корекцію форм, методів і технологій навчання фахівців технічного профілю;

- удосконалити систему управління військовою освітою взагалі та ВВНЗ технічного профілю зокрема.

Огляд останніх досліджень та публікацій. Серед питань організації наукових досліджень у ВВНЗ, як правило, розглядаються такі: моделі та методи планування й управління науковими дослідженнями у ЗС України [1], організація наукової і науково-технічної діяльності (ННТД) у ЗС України в особливий період [2], моделі організації системи науково-дослідної роботи вищих навчальних закладів [3], науково-методичний апарат моніторингу ННТД наукових i науково-педагогічних працівників, спрямованої на забезпечення та удосконалення освітньої діяльності ВВН3 [4].

У доступних нам джерелах не виявлено наукових публікацій, де розглядалися б проблеми організації наукових досліджень для задоволення потреб військової освіти України взагалі та ВВНЗ технічного профілю підготовки зокрема. Зазначене вище зумовлює потребу у проведені наукового пошуку шляхів побудови моделі наукового забезпечення функціонування та розвитку ВВНЗ ЗС України як необхідної складової забезпечення високого рівня підготовленості випускників ВВН3 до майбутньої професійної діяльності.

Мета статті - визначити місце та роль (можливі варіанти використання) наукових досліджень у забезпеченні освітньої діяльності вищих військових навчальних закладів.

Виклад основного матеріалу. Освітня діяльність ВВНЗ (діяльність, що проводиться $з$ метою забезпечення здобуття вищої, післядипломної освіти й задоволення інших освітніх потреб здобувачів вищої освіти та інших осіб) спрямована на підготовку військових фахівців високої професійної кваліфікації, з високими морально-діловими якостями, патріотів України, здатних якісно виконувати бойові завдання відповідно до спеціалізації підготовки. Наукова (науково-технічна) продукція, що створюється в інтересах ВВНЗ під час проведення наукових досліджень, покликана гарантувати якість освітніх послуг, які надає заклад, та відповідність підготовки випускників вимогам сучасних збройних сил.

Наукове дослідження - це інтелектуальна творча діяльність, спрямована на всебічне вивчення об'єкту, процесу або явища, їх структури і зв'язків за допомогою наукових методів та спеціальних приладів, яка має на меті встановлення закономірностей їх (об'єкту, процесу або явища) виникнення, розвитку й перетворення в інтересах раціонального використання у практичній діяльності людей. Визначимо місце та роль наукових досліджень у забезпеченні освітньої діяльності вищих військових навчальних закладів, 
аналізуючи питання управління освітньою діяльністю ВВНЗ та організацію освітнього процесу на кафедрі.

\section{Важсливість проведення наукових досліджень для вирішення проблем} управління освімньою діяльністю ВВНЗ та викладання навчальних дисциплін.

Науковцям (педагогам, психологам) i керівникам освіти, які прагнуть усвідомити сучасну освітню й виховну ситуацію, проаналізувати успіхи та недоліки, знайти резерви, побачити нові стратегічні орієнтири, необхідно оволодіти методологією творчого пошуку, методикою організації i проведення дослідно-пошукової, експериментальної роботи.

Оскільки будь-який закон є конкретно-історичним феноменом, зі зміною відповідних умов, із розвитком практики й пізнання одні закони сходять зі сцени або видозмінюються, інші з'являються. Глибокі зміни умов навчання i виховання за останні десятиріччя вимагають нових знань про закономірності цього процесу. Результативність реформування, модернізації освіти у ЗС України прямо залежить від розвитку фундаментальних досліджень у галузі теорії навчання, від виявлення нових закономірностей цього складного структурного процесу в умовах постійного розширення культурно-освітнього простору, розвитку неперервної, особистісно орієнтованої, полікультурної освіти.

Педагоги вищої школи, насамперед, цікавляться створенням навчальних планів, програм, підручників, методичних рекомендацій, різноманітних дидактичних матеріалів та інших засобів. Без методичних розробок, як іноді називають перераховані праці, не можливо ефективно здійснювати освітній процес. Але цілком очевидно, і це чудово розуміють самі науково-педагогічні працівники, що фундаментальні та прикладні наукові дослідження є основою зазначених методичних розробок. Передусім, мова йде про дослідження, спрямовані на удосконалення існуючих або розроблення нових форм, методів i способів проведення занять, їх апробацію. Таким чином результати наукових досліджень реалізовуються в освітній діяльності.

Потрібно враховувати ще одне важливе завдання науково-педагогічних i наукових працівників, що потребує досвіду проведення наукових досліджень - бути експертами при ухваленні важливих рішень щодо удосконалення функціонування й розвитку ВВНЗ зокрема та військової освіти в цілому. Адже таку експертизу можуть здійснити лише фахівці 3 глибоким рівнем спеціальних знань.

Проте, незважаючи на вищевикладене, наукові дослідження для вирішення проблем управління освітньою діяльністю ВВНЗ та викладання навчальних дисциплін вищими військовими навчальними закладами не замовляються, як виключення 3 правил, на замовлення Департаменту військової освіти, науки, соціальної та гуманітарної політики Міністерства оборони України проводяться деякі дослідження в інтересах системи військової освіти й мінімальна кількість досліджень в інтересах ВВН3. 
Роль наукових досліджень в організації освітнього процесу ВВНЗ. Закон України «Про вищу освіту» [7] визначає, що:

- магістерський рівень вищої освіти передбачає здобуття особою загальних засад методології наукової та/або професійної діяльності;

- освітньо-науковий рівень вищої освіти (доктор філософії) завбачує здобуття особою теоретичних знань, умінь, навичок та інших компетентностей, достатніх для продукування нових ідей, розв'язання комплексних проблем у галузі професійної та/або дослідницько-інноваційної діяльності, оволодіння методологією наукової і педагогічної діяльності, а також проведення власного наукового дослідження.

Розвивати широту мислення, набувати навичок науково-дослідницької роботи неможливо без участі у проведенні реальних досліджень. Саме тому під час організації освітнього процесу у ВВНЗ здобувачі вищої освіти (особи, які навчаються у вищому навчальному закладі на певному рівні вищої освіти 3 метою здобуття відповідного ступеня та кваліфікації) виконують кваліфікаційні роботи (курсові, дипломні, магістерські, дисертаційні), беруть участь у роботі наукових товариств.

Кваліфікаційна робота здобувачів вищої освіти є:

- найважливішим елементом навчального процесу, основним засобом організації систематичної та самостійної роботи в опануванні вибраної спеціальності;

- формою самостійної освітньої діяльності здобувача вищої освіти, у процесі якої він одержує знання, уміння й навички у проведенні наукових досліджень. Вона дає можливість використовувати набуті знання в обгрунтуванні певних теоретичних положень із вибраної теми, а також опановувати шляхи впровадження теоретичних знань у практичну діяльність;

- формою підсумкової атестації на здобуття освітньо-кваліфікаційного рівня магістр (спеціаліст), доктор філософії. Кваліфікаційна робота визначає загальноосвітню та професійну зрілість здобувача, його наукову й спеціальну підготовку, уміння діалектично мислити та творчо застосовувати одержані знання при розв'язанні практичних завдань.

У вищих навчальних закладах та їхніх структурних підрозділах діють наукові товариства курсантів, слухачів, аспірантів, докторантів і молодих учених, які є частиною системи громадського самоврядування відповідних вищих навчальних закладів. Наукове товариство створюється для забезпечення захисту прав та інтересів осіб, які навчаються або працюють у вищому навчальному закладі, зокрема щодо питань наукової діяльності, підтримки наукоємних ідей, інновацій та обміну знаннями.

У [6] висвітлено ряд проблемних питань організації й проведення наукової роботи курсантів у ВВНЗ. Основними з них, на наш погляд, є: практично відсутня інтеграція системи освіти та науки ВВН3 3 виробництвом, і навіть 3 установами оборонно-промислового комплексу; недостатній престиж ННТД серед молоді; застаріла навчально-матеріальна 
база курсантських конструкторських бюро; відсутність фінансування й матеріального забезпечення прикладних і пошукових досліджень курсантів.

Окрім того, сьогодні відсутні дієві механізми залучення курсантів, слухачів, аспірантів, докторантів до проведення наукових досліджень в інтересах ВBH3.

Наукові дослідження як передумова оновлення змісту освітнього процесу та розвитку НПП.

Наявність новітніх зразків озброєння та військової техніки значною мірою забезпечує перевагу в сучасній війні. Проте недостатньо мати досконалішу техніку, необхідно навчити особовий склад обслуги (розрахунку, екіпажу) ефективно використовувати іiі можливості. А це вимагає формувати зміст навчання курсантів (слухачів, ад'юнктів, докторантів) з урахуванням нових досягнень науки й техніки, що неможливо без участі НПП у наукових дослідженнях щодо розроблення нових зразків озброєння та військової техніки. Особливо важлива участь у таких дослідженнях НПП ВВНЗ технічного профілю підготовки.

Будь-який поважаючий себе сучасний педагог прямо чи побіжно, безпосередньо чи опосередковано, так чи інакше бере участь в експериментах, або підготовлених ним самим, або організованих вищим навчальним закладом чи зовнішнім замовником. Об'єктом експериментальної діяльності завжди в кінцевому підсумку є здобувачі вищої освіти. Ось чому знання та уміння організувати і провести експеримент набувають особливого значення й вимагають від науково-педагогічного працівника величезної відповідальності та бездоганної компетентності й професіоналізму. Влучно про це свого часу сказав А. Дістервег: «Без прагнення до наукової роботи учитель ... потрапляє до влади трьох демонів: механістичності, рутинності, банальності. Він дерев'яніє, кам'яніє, опускається».

Кожен викладач має бути експериментатором і дослідником, тільки тоді його праця стане творчою й ефективною. Творити, шукати, експериментувати, постійно оновлювати зміст і методи роботи з формування особистості здобувача вищої освіти (курсанта, слухача, ад'юнкта, докторанта) $є$ тепер не лише правом, але й обов'язком учителів та викладачів, що офіційно закріплено в Законі України «Про освіту».

Таким чином, у нинішніх умовах повноцінна освіта без розвитку науки у ВВНЗ неможлива. Проте погляди на те, якою саме вона має бути, суттєво відрізняються. Один із варіантів організації науки у ВНЗ полягає в тому, щоб закрити в Україні більшість наукових тематик «не світового рівня» i зосередитися на підтримці двох-трьох справді «проривних» напрямів. Такий крок означав би катастрофічне зниження професійного рівня викладачів у ВВН3, а відтак - рівня їх випускників. Адже саме заняття наукою (нехай і не найвищого світового, але принаймні відповідного фахового рівня) тримає доцентів і професорів в «інтелектуальному тонусі» [5].

Звичайно, що цього замало. Необхідно на підставі аналізу проблем організації наукових досліджень в інтересах системи військової освіти 
взагалі та функціонування й розвитку ВВНЗ зокрема запропонувати перспективну модель організації проведення наукових досліджень.

Основними недоліками існуючої системи організації наукових досліджень під час їх замовлення, на наш погляд, є такі, як:

- кафедри відіграють пасивно-допоміжну (щодо наукових підрозділів ВВНЗ) роль у процесі замовлення НДР;

- не визначено, який відсоток наукового потенціалу ВВНЗ його начальник має право використати для проведення наукових досліджень в інтересах забезпечення функціонування та розвитку закладу (фактично це відбувається за остаточним принципом);

- не визначено роль i повноваження науково-організаційних підрозділів ВВНЗ у процесі замовлення НДР. У багатьох випадках ці підрозділи виконують завдання лише щодо узагальнення поданих пропозицій, їх погодження iз Воєнно-науковим управлінням (ВНУ) Генерального штабу (ГШ) ЗС України;

- заявки (тематичні картки) на виконання НДР ВВНЗ мають в обов'язковому порядку погоджуватися із ВНУ ГШ ЗС України [7], для якого питання удосконалення військової освіти, розвитку ВВНЗ не є профільними та пріоритетними.

Як один із наслідків існування перерахованих недоліків замовлення НДР - наукові дослідження, що виконуються в наукових підрозділах та кафедрах, не мають прямого відношення до освітнього процесу ВВНЗ.

Проблемними питаннями організації виконання наукових досліджень для забезпечення функціонування та розвитку ВВНЗ залишаються такі:

- забезпечення мотивації включення наукових працівників наукових підрозділів ВВНЗ в освітню діяльність, без чого неможливе знання проблематики наукових досліджень в інтересах закладу. Їх залучення до проведення навчальних занять нормативно не врегульовано, керівниками наукових підрозділів не враховується під час визначення рейтингу наукових працівників, відсутні механізми фінансового заохочення при над нормованому навантаженні наукових працівників;

- низька активність науково-педагогічних працівників (НПП) кафедр у виконанні НДР. Багато НПП вважають наукову роботу другорядним елементом своєї діяльності й налаштовані на «ретрансляцію» знань за «стандартною» методикою викладання. Формуванню такої точки зору «сприяє» перевищення визначеного в [7] обсягу навчального навантаження НПП.

На наш погляд, основними причинами існуючих недоліків в організації наукових досліджень для забезпечення освітньої діяльності ВВНЗ є:

- відсутність ефективних механізмів замовлення (у тому числі фінансування) тематики наукових досліджень в інтересах забезпечення функціонування та розвитку ВВНЗ, формування тимчасових творчих колективів, реалізації результатів досліджень у ВВНЗ; 
- недосконала нормативно-правова база, що регламентує організацію наукового забезпечення функціонування та розвитку ВВНЗ.

Зазначене вище зумовлює потребу у формуванні моделі організації наукового забезпечення освітньої діяльності ВВНЗ, що б дала змогу спрямовувати наукові дослідження на вирішення проблем функціонування та розвитку ВВНЗ ЗС України.

У перспективній моделі організації наукового забезпечення освітньої діяльності ВВНЗ доцільно розглядати структурні елементи (суб'єкти наукового забезпечення, структурні підрозділи, у які вони адміністративно об'єднуються, керівники ВВНЗ), їх завдання та порядок взаємодії під час замовлення, виконання, приймання наукових досліджень та реалізації наукових результатів.

Суб’єктами наукового забезпечення освітньої діяльності ВВНЗ можуть бути: наукові, науково-педагогічні працівники, здобувачі вищої освіти (курсанти, слухачі, ад’юнкти, докторанти), інші працівники вищих навчальних закладів, а також працівники підприємств, які спільно з вищими навчальними закладами проводять наукову, науково-технічну й інноваційну діяльність.

Серед структурних підрозділів, у яких адміністративно об'єднані суб'єкти наукового забезпечення ВВН3, доцільно розрізняти підрозділи виконавці наукових досліджень (кафедра, науково-дослідна лабораторія, науково-дослідний відділ) та підрозділи - управління науковими дослідженнями (науково-організаційний відділ (відділення), управління, науково-методичний центр тощо).

Основним структурним підрозділом ВВНЗ у перспективній моделі організації наукових досліджень для забезпечення функціонування та розвитку ВВНЗ ЗС України технічного профілю має бути кафедра. Згідно із Законом України «Про вищу освіту» [7], кафедра є базовим структурним підрозділом вищого навчального закладу, що проводить освітню, методичну та/або наукову діяльність за певною спеціальністю (спеціалізацією) чи міжгалузевою групою спеціальностей, до складу якої входить не менше п'яти науково-педагогічних працівників, зокрема три з них із науковим ступенем або вченим (почесним) званням.

Кафедра має відігравати провідну роль у процесі формування замовлення на наукову (науково-технічну) продукцію в інтересах ВВНЗ, оскільки саме вона $є$ основним підрозділом, що відповідає за якість підготовки військових фахівців для 3С України. 3 досвіду кафедри щодо організації навчального процесу та забезпечення якості освітньої діяльності визначають проблеми, що так чи інакше ускладнюють його організацію i проведення (систему науково-методичних i педагогічних заходів, спрямованих на розвиток особистості шляхом формування та застосування іiі компетентностей), і потребують наукових досліджень з метою знаходження раціональних шляхів їх вирішення на вузівському або державному рівнях. 
На науково-організаційний підрозділ доцільно покласти завдання щодо перевірки якості замовлення (відпрацювання виконавцями заявок а замовниками тематичних карток на НДР, проектів Т3 (ТТЗ)), організації (формування тимчасових творчих колективів (ТТК), робочих програм виконання НДР, перевірки попереднього розрахунку працевитрат на проведення НДР та наявного часового ресурсу членів ТТК на проведення наукових досліджень), контролю за своєчасністю проведення наукових досліджень згідно з річним планом ННТД ВВНЗ, відповідності звітів про НДР завданням, поставленим у ТЗ (ТТ3), правильності їх оформлення та впровадження наукових результатів НДР, що виконувалися для забезпечення освітньої діяльності ВВНЗ.

Керівник вищого навчального закладу має відповідати за координацію діяльності суб'єктів наукового забезпечення, фінансування наукових досліджень та впровадження їх результатів в освітню діяльність ВВНЗ, що йому підпорядковується.

В основу організації взаємодії суб'єктів наукових досліджень, структурних підрозділів, у які вони об'єднані, та керівників ВВНЗ пропонуємо покласти такий порядок замовлення, виконання наукових досліджень для забезпечення функціонування й розвитку ВВНЗ:

- у середовищі кафедри визначаються теми наукових досліджень, які в найближчій перспективі дадуть найкращий ефект для вирішення об'єктивних проблем підготовки військових фахівців. На підставі цього прогнозу розробляється проект заявки на виконання НДР, що затверджується на засіданні кафедри та подається до науково-організаційного підрозділу ВВНЗ;

- науково-організаційний підрозділ узагальнює подані кафедрами заявки на проведення НДР і тематичні картки на НДР, подані замовниками наукових досліджень, перевіряє їх відповідність Стратегії (концепції) розвитку ВВНЗ та можливостям наукового потенціалу закладу щодо їх виконання, правильність оформлення i відсутність дублювання (недопущення випадків повторів) тематики досліджень. Лише після перевірки зазначених документів начальником науково-організаційного підрозділу вони мають подаватися на погодження заступнику начальника ВВНЗ з навчальної та наукової (наукової) роботи а далі - на затвердження начальнику ВВНЗ;

- у подальшому ТК на НДР, спрямовані на забезпечення функціонування й розвитку ВВНЗ ЗС України, погоджуються начальником ВВНЗ з Департаментом військової освіти, науки, соціальної та гуманітарної політики МО України (на який покладено завдання щодо визначення перспектив розвитку військової освіти та науки, ННТД у військовій сфері, їх поступове наближення до стандартів держав - членів НАТО [10]) та ВНУ ГШ ЗС України.

При цьому відповідальність за своєчасність завершення досліджень, якість та обгрунтованість отриманих результатів несуть науковий керівник та відповідальний виконавець роботи, як це й передбачено [9]. 
Висновки. Організація наукового забезпечення освітньої діяльності ВВНЗ відповідно до запропонованої моделі дасть змогу:

- підвищувати наукову кваліфікацію науково-педагогічних працівників кафедр;

- покращувати методичне забезпечення як освітньої діяльності ВВНЗ в цілому, так освітнього процесу кафедри зокрема;

- удосконалювати науково-дослідницьку частину навчальноматеріальної бази кафедр та наукових підрозділів ВВНЗ;

- зосереджувати основні зусилля наукових i науково-педагогічних працівників ВВНЗ на проведенні наукових досліджень щодо вирішення актуальних для освітньої діяльності ВВНЗ проблем.

Наразі керівними документами не визначено запропоновану модель організації виконання НДР в інтересах освітньої діяльності ВВНЗ ЗС України.

Перспективою подальших досліджень $\epsilon$ розроблення механізмів організації проведення наукових досліджень (визначення практичної проблеми та замовлення, організації виконання, упровадження наукових результатів) для забезпечення функціонування й розвитку системи військової освіти України взагалі та освітньої діяльності ВВНЗ технічного профілю зокрема.

\section{ЛІТЕРАТУРА}

1. Алімпієв А. М. Моделі і методи планування та управління науковими дослідженнями / А. М. Алімпієв, Д. А. Гриб, Б. О. Демідов та ін. // Наука і техніка Повітряних Сил Збройних Сил України. - 2014. - № 2(15). - С. 173-176.

2. Сафронов О. В. Організація наукової та науково-технічної діяльності у Збройних Силах України в особливий період / О. В. Сафронов, О. А. Прохоров, М. Ф. Полторак // Військова освіта. - 2015. - № 2. - С. 211-220.

3. Степашко В. Модель науково-дослідної роботи вищого навчального закладу [Електронний http://library.udpu.org.ua/library_files/psuh_pedagog_probl_silsk_shkolu/17/visnuk_3.pdf

4. Капосльоз Г. В. Деякі аспекти моніторингу наукового забезпечення функціонування та розвитку педагогічної системи вищого військового навчального закладу / Г. В. Капосльоз // Військова освіта. - 2015. - № 2. - С. 93-105.

5. Навіщо суспільству сьогодні потрібна наука? М. Стріха, К. Матвієнко. [Електронний pecypc]. - Режим доступу : https://day.kyiv.ua/uk/article/panoramadnya/navishcho-suspilstvu-sogodni-potribna-nauka.

6. Звіт про науково-дослідну роботу “Обгрунтування перспективної системи наукового забезпечення функціонування та розвитку військової освіти. Організація наукових досліджень у вищих навчальних закладах технічного профілю" (проміжний) (шифр “КОНЦЕПЦІЯ-НЗ”). - Житомир: ЖВІ, 2017. - 78 с.

7. Закон України: Про вищу освіту від 01.07.2014 № 1556-VII [Електронний ресурс] : Режим доступу : http://zakon5.rada.gov.ua/laws/ show/1556-18.

8. Положення про вищі військові навчальні заклади, затверджене наказом Міністерства оборони України від 27.05.2015 № 240 [Електронний ресурс]. - Режим доступу : http://zakon2.rada.gov.ua/laws/show/z0706-15. 
9. Положення про організацію наукової і науково-технічної діяльності у Збройних Силах України, затверджене наказом Міністерства оборони України від 26.07.2016 № 385 [Електронний ресурс]. - Режим доступу : http://zakon2.rada.gov.ua/laws/show/z1172-16.

10. Департамент військової освіти, науки, соціальної та гуманітарної політики Міністерства оборони України [Електронний ресурс]. - Режим доступу : http://www.mil.gov.ua/ministry/struktura-aparatu-ministerstva/departament-vijskovoi-osvitinauki-soczialnoi-ta-gumani tarnoi-politiki-ministerstva-oboroni-ukraini.html

\section{REFERENCES}

1. Alimpiev, A. M., Grib, D. A., Demidov, B .A., Olizarenko, S. A., Naumenko, M. V. (2014) «Modeli i metodi planuvannya ta upravlinnya naukovimi doslidzhenyami» [Models and methods of planning and management science research], Science and Technology of the Air Force of Ukraine, Kharkiv, № 2 (15), pp. 173-176.

2. Safronov, O. V., Prohorov, A. A., Poltoruk, M. F. (2015) «Organizatciya naukovoi ta naukovo-tehnichnoi diyalnosti u Zbroinih Silah Ukraini v osoblivyi period» [Organization of scientific and scientific-technical activity in the Armed Forces during the special period], Military Education, Kiev, № 2, pp. 211-220.

3. Stepashko, V. (2006) «Model naukovo-doslidnoi roboti visshogo navchalnogo zakladu» [Model of research work of a Higher Educational Institution], available at: http://library.udpu.org.ua/library_files/psuh_pedagog_probl_silsk_shkolu/17/visnuk_3.pdf.

4. Kaposlyoz, G. V. (2015) «Deyaki aspekti monitoringu naukovogo zabezpechennya funkcionuvannya ta rozvitku pedagogichnoi sistemi vischogo vyiskovogo navchalnogo zakladu» [Some aspects of the monitoring of scientific software development and functioning of pedagogical system Higher Military Educational Institution] Military Education, Kiev, № 2, pp. 93-105.

5. Striha, M., Matviyenko, K. (2009) «Navischo suspilstvu syogodni potribna nauka?» [Why society today needs science?], available at: https://day.kyiv.ua/uk/article/panoramadnya/navishcho-suspilstvu-sogodni-potribna-nauka.

6. Report on research work (2017) «Obgruntuvannya perspektivnoi sistemi naukovogo zabezpechennya funkcionuvannya ta rozvitku vyiskovoi osviti. Organizaciya naukovih doslidzen $\mathrm{u}$ vischih navchalnih zakladah tehnichnogo profilyu» [Reasoning of a perspective system of scientific support for the functioning and development of military education. Organization of scientific research in higher educational institutions of technical profile], Zhytomyr, $78 \mathrm{p}$.

7. Law of Ukraine «On Higher Education», dated July 1, 2014, n.o. 1556-VII, available at: http// zakon5.rada.gov.ua/laws/ show/1556-18.

8. Order of the Ministry of Defense of Ukraine «On Approval of the Regulations on Higher Military Educational Institutions», dated May 27, 2015, n.o. 240, available at: http://zakon2.rada.gov.ua/laws/show/z0706-15.

9. Order of the Ministry of Defense of Ukraine «On Approval of the Regulations on organization of scientific and scientific-technical activities in the Armed Forces of Ukraine», dated July 26, 2016, n.o. 385, available at: http://zakon2.rada.gov.ua/laws/show/z1172-16.

10. Department of Military Education, Science, Social and Humanitarian Policy of the Ministry of Defense of Ukraine, available at: http://www.mil.gov.ua/ministry/struktura-aparatuministerstva/departament-vijskovoi-osviti-nauki-soczialnoi-ta-gumani tarnoi-politiki-

ministerstva-oboroni-ukraini.html 


\section{РЕЗЮМЕ}

Роман Дзюбчук, кандидат технических наук, старший научный сотрудник, Житомирский военный институт имени С. П. Королёва

Григорий Капослёз, кандидат психологических наук, старший научный сотрудник,

Олег Розумный,

Национальный университет обороны Украины имени Ивана Черняховського

\section{Место и роль научных исследований в обеспечении образовательной деятельности высшего военного учебного заведения технического профиля подготовки}

В статье определень место и роль научных исследований в обеспечении образовательной деятельности высших военных учебных заведений (управлении образовательной деятельностью и развитием учебного заведения, организации образовательного прочесса на кафедре), проблемные вопросы организации научных исследований для обеспечения образовательной деятельности выстего военного учебного заведения и возможные пути их решения.

Ключевые слова: научное обеспечение; высшее военное учебное заведение; научное исследование; модель организации.

\section{SUMMARY \\ Roman Dziubchuk, Candidate of Technical Science, Senior Researcher, Korolyov Zhytomyr Military Institute Grigoriy Kaposlyoz, Candidate of Psychological Science, \\ Senior Researcher, \\ Oleg Rozumniy \\ National Defense University of Ukraine named after Ivan Cherniakhovskyi}

The place and role of scientific research in supplying the educational activities of higher education institutions of technical profile

Introduction. Military higher education institutions (HEI) of technical profile feel necessity in scientific research to satisfy a row of interconnected needs of military education. In available resources, publications revealing questions of organizing scientific research for satisfying needs of military education in Ukraine and higher educational institutions of technical profile were not found.

Purpose. To determine the place and role (including possible variants of usage) of scientific research in supplying the educational activities in military HEI.

Methods. The method of analysis and synthesis and the method of expert evaluations are used.

Results. While determining the place and role of scientific research in supplying the educational activities in military HEI: 
importance of scientific research in solving problems considering management of educational activities and teaching academic disciplines in military HEI was proved;

place of scientific research in organization of educational process was determined;

attention on the role of scientific research in actualization of educational content and development of lecturers and researchers was paid.

In order to solve the problems in organization of scientific research for the interests of military HEI, a perspective model for organizing the scientific support of educational activities in military HEI has been developed. It defines: structural elements (subjects of scientific support, structural units in which they are administratively united, directorate of military HEI), their tasks and the way of interaction during the ordering, execution, acceptance of scientific researches and implementation of scientific results.

Originality. A model for organizing the scientific support of educational activities in military HEI was first proposed.

Conclusion. Up to now, guideline documents do not define a model of conducting research projects to meet needs of educational activities of military HEI of Armed Forces of Ukraine. Perspective of further research is creation of mechanism of conducting scientific research to supply functioning and development of system of military education in general and educational activities of HEI of technical profile in particular.

Key words: scientific support; military higher education institution; scientific research; model of organization. 